\title{
USTĘPUJACA AMBIWALENCJA WŁADZY WYKONAWCZEJ, CZYLI WSPÓŁPRACA ZAGRANICZNA POLSKICH REGIONÓW A POLITYKA ZAGRANICZNA PAŃSTWA
}

W funkcjonowanie demokratycznej władzy wykonawczej wpisują się nieustanne dylematy. Dotyczą one szczególnie podejścia do podmiotów i procesów podlegających egzekutywie. Kwestie masowe są na ogół uregulowane, a prawo jest dlań wyznacznikiem i gwarancją zarazem. Kwestie niszowe, uregulowane powierzchownie lub wycinkowo, władza wykonawcza dostrzega wprost proporcjonalnie do ich aspiracji względem jej prerogatyw. Reaguje nań ad hoc (gdy pojawiają się incydentalnie), albo systemowo (gdy ich częstotliwość wzrasta) - kreując legislację (law in action). Przykładem może być tu podejście państwa do współpracy zagranicznej polskich regionów (województw). Kilka aspektów tego zagadnienia warto z pewnością przybliżyć.

\section{Państwo a regiony w stosunkach międzynarodowych}

W zależności od prawnego charakteru stosunków między centrum a regionami można wyróżnić państwa zdecentralizowane i scentralizowane. W państwach zdecentralizowanych organy regionalne tworzone są niezależnie od organów centralnych (np. Wielka Brytania). W krajach scentralizowanych podporządkowanie organów regionalnych przybiera postać wyznaczania przez organy centralne urzędników do kierowania sprawami w regionie (np. Finlandia). Klasyczną formą są tu państwa unitarne, w których - siłą rzeczy - status regionów jest stosunkowo najsłabszy. Rzadko też zdarza się, aby istnienie regionów było wpisane do konstytucji (tak jest np. w Holandii i Portugalii) ${ }^{1}$. W państwie unitarnym suwerenność prawna przysługuje wyłącznie organom centralnym, a w państwie federalnym podzielona jest pomiędzy federację i jej człony (w Niemczech - landy, w Austrii - landy czy

1 K. Tomaszewski, Regiony w procesie integracji europejskiej, Warszawa 2007, s. 22-26 i 30. Por. przykładowo: A. Warleigh-Lack, M. Stegmann, 'Usages of Europe' and Europeanisation: Evidence from the Regionalisation of Sweden, "European Integration" 2012, t. 34, nr 4, s. 379-396. 
kraje związkowe, w Szwajcarii - kantony, w USA - stany, w Kanadzie - prowincje, w Belgii - regiony). $Z$ tego powodu samodzielność regionów federalnych jest dużo szersza niż regionów funkcjonujących w państwie unitarnym. W zakresie wydawania decyzji politycznych (tworzenia prawa) regiony federalne posiadają w zasadzie jednakowe jak państwo kompetencje, odpowiadające przyjętemu wzorcowi podziału. Charakterystyczną cechą omawianych regionów jest ich duża samodzielność, z której korzystają na mocy konstytucji federalnych ${ }^{2}$. Ponadto, są wyposażone we własne parlamenty i rządy oraz dysponują szerokimi uprawnieniami - np.: landy niemieckie są upoważnione, za zgodą Rządu Federalnego, do dokonywania transferu praw zwierzchnich na rzecz instytucji transgranicznych w sąsiednich regionach (art. 24 ust. 1 ustawy zasadniczej Republiki Federalnej Niemiec), a landy austriackie - do zawierania umów z graniczącymi z Austrią państwami lub ich częściami składowymi (art. 16 ust. 1 Konstytucji Austrii) ${ }^{3}$.

Znaczną aktywność przejawiają też regiony w krajach zregionalizowanych. Jest to forma pośrednia między państwem federalnym a unitarnym o strukturze zdecentralizowanej, w których regiony są wyodrębnione w konstytucji, co stanowi gwarancję prawną ich istnienia, a ponadto mają one określone kompetencje w zakresie władzy wykonawczej, ale bez uprawnień w zakresie prawodawstwa i sądownictwa ${ }^{4}$. Jednostki wewnątrzpaństwowe korzystają z konstytucyjnie zagwarantowanej autonomii. Podział terytorialny opiera się najczęściej na uznaniu danego regionu ze względu na tradycje historyczne lub zamieszkującą go grupę etniczną albo językową (kraje zregionalizowane: Hiszpania i Włochy były wcześniej zarządzane w sposób całkowicie unitarny). Przyznanie autonomii jednostkom terytorialnym oznacza wzrost poziomu ochrony interesów mieszkańców. Bardziej działa tu jednak aspekt socjologiczny niż prawny. Właśnie w ramach europejskich państw zregionalizowanych uaktywniła się grupa jednostek terytorialnych, która przejawia zdecydowanie większą aktywność w dążeniach do emancypacji i umocnienia swojej pozycji geopolitycznej. Chodzi tu zwłaszcza o regiony hiszpańskie (zwłaszcza Katalonię), które charakteryzują się silnym poczuciem przynależności ich mieszkańców oraz długimi tradycjami historycznymi, przy jednocześnie głęboko zakorzenionej opozycyjności wobec rządu centralnego ${ }^{5}$.

W rozważaniach status quo i perspektyw międzynarodowej aktywności regionów, przyjmując za punkt wyjścia różnorodność rozwiązań konstytucyjnych, należy też wziąć pod uwagę podejście państw macierzystych (wobec regionów) do stosunków międzynarodowych.

J. Szymański, Podstawy prawne współpracy transgranicznej i regionalnej Polski ze wschodnimi sąsiadami, Suwałki 2002, s. 25 (maszynopis udostępniony przez autora, w związku z brakiem egzemplarzy drukowanych), s. 25.

M. Perkowski, Międzynarodowa współpraca województw w prawie i praktyce, Białystok 2013, s. 41. K. Tomaszewski, Regiony..., op. cit., s. 23-27. 
Współczesne stosunki międzynarodowe są niewątpliwie skomplikowanym zbiorem procesów i zjawisk (te ostatnie - w odróżnieniu od procesów - człowiek obserwuje, analizuje i stara się zrozumieć, ale kontrolować nie potrafi). Dwudziestowieczne katastrofy wojenne i ich dramatyczne skutki zdeterminowały główne paradygmaty współczesnych stosunków międzynarodowych. Po pierwsze współpraca stała się zasadą. Należy ją realizować od relacji bilateralnych, poprzez regionalne, aż po globalizację, choćby pozostawała sztuką dla sztuki i sposobem podtrzymania relacji. W dziedzinach merytorycznych celem państw i innych podmiotów stała się wszechstronna progresja. Skoro więc współpraca winna być rozwojowa, to globalizacja doprasza do obrotu międzynarodowego tych, którzy tego chcą i powoduje, że powszechne staje się dążenie do ekspansji dotychczasowej aktywności ponad dotychczasowe ograniczenia. Różne typy aktorów krajowych wstępują na poziom międzynarodowy, bo stał się on dostępny, a przez to staje się on jeszcze dostępniejszy (progresja) ${ }^{6}$. Tradycyjna współpraca międzypaństwowa, typowa dla wcześniejszych okresów historycznych, uzupełniana jest nową siecią powiązań między społecznościami lokalnymi oraz regionalnymi w formie współpracy transgranicznej, partnerstwa gmin i miast oraz międzynarodowej współpracy regionów ${ }^{7}$ W tym kontekście powstaje pytanie: w jakiej pozycji sytuuje się społeczność regionalna i lokalna oraz ich struktury instytucjonalne? ${ }^{8}$

Podmiotowość społeczności regionalnej to możliwość swobodnego jej istnienia i działania w ramach społeczności państwowej, a także autentycznego stanowienia o sobie we wszystkich płaszczyznach codziennej egzystencji. Oznacza to, że (...) chodzi ostatecznie o stworzenie takich struktur polityczno-społeczno-gospodarczych, które gwarantować będą faktyczną autonomię społeczności regionalnej, jako warunek realizacji podmiotowości, jak i płaszczyznę działania, dzięki której owa podmiotowość może być realizowana ${ }^{9}$. Idąc ścieżką teorii multilevel governance Komisja Europejska dąży do zaangażowania regionów we współpracę na szczeblu europejskim i wzmocnienia procesu ,integracji oddolnej”. Taka postawa Komisji jest pozytywnie przyjmowana zarówno przez państwa, jak i regiony. Dla pierwszych wiąże się to $\mathrm{z}$ potwierdzeniem ich roli, jako zasadniczych podmiotów procesu integracji, a dla regionów oznacza podmiotową aktywizację na forum międzynarodowym ${ }^{10}$. Komisja Europejska (a właściwie cała Unia Europejska) opiera

6 M. Perkowski, Międzynarodowa współpraca..., op. cit., s. 50.

$7 \quad$ K. Jóskowiak, Samorząd terytorialny w procesie integracji europejskiej Polskie doświadczenia i wnioski na przyszłość, Katowice 2008, s. 9. Por.: Zrównoważony rozwój terenów przygranicznych, B. Kościk, M. Sławińska (red.), Lublin 2010.

8 I. Popiuk-Rysińska, Uczestnicy stosunków międzynarodowych, ich interesy i oddziaływania, (w:) Stosunki międzynarodowe. Geneza, struktura, funkcjonowanie, E. Haliżak, I. Popiuk-Rysińska (red.), Warszawa 1994, s. 98. Por.: K. Jóskowiak, Samorząd terytorialny..., op. cit., s. 14.

$9 \quad$ H. Skorowski, Regionalizm czynnikiem dynamizmu współczesnego państwa, tekst wygłoszony podczas Mazowieckiego Sejmiku Kultury, Warszawa 16 czerwca 2011 (maszynopis), s. 2-5.

10 M. Perkowski, Międzynarodowa współpraca..., op. cit., s. 296. Por.: K. Tomaszewski, Regiony w procesie..., op. cit., Warszawa 2007, s. 142. 
politykę regionalną na zasadzie partnerstwa, polegającej na tym, że zarówno na etapie programowania, jak i realizacji, powinni uczestniczyć wszyscy zainteresowani partnerzy społeczni. Wymaga to współpracy pomiędzy Komisją Europejską a odpowiednimi władzami publicznymi danego państwa na szczeblu krajowym (państwo), regionalnym (województwa) i lokalnym (gminy, powiaty), a także współpracy z partnerami gospodarczymi i społecznymi. Zasada partnerstwa może być rozumiana: wertykalnie (współpraca Komisji Europejskiej z odpowiednimi władzami krajowymi, regionalnymi i lokalnymi, dzięki czemu pomoc trafia do odpowiednich obszarów) i horyzontalnie (konsultacje władz samorządowych i rządowych z partnerami społecznymi najbardziej zainteresowanymi planowanymi działaniami, dzięki czemu zwiększa się efektywność i celowość pomocy) ${ }^{11}$.

Państwo wobec tak złożonych i dynamicznych stosunków międzynarodowych nie może reagować tylko ad hoc, lecz musi wykształcić i realizować odpowiednią politykę. Pojęcie ,polityka zagraniczna państwa” jest szerokie i ujmowane na wiele sposobów. Przykładową definicję proponuje Jacek Pietraś, według którego polityka zagraniczna państwa to proces formułowania i realizacji celów zewnątrzpaństwowych, odzwierciedlających interesy narodu i jego części składowych ${ }^{12}$. Do tych ostatnich należą zapewne regiony i/lub społeczności regionalne. Skoro ich interes realizowany międzynarodowo ma być odzwierciedlony w polityce zagranicznej państwa, należy określić uczestników i ramy tego procesu.

\section{Czy polskie województwa są europejskimi regionami?}

$\mathrm{Za}$ region można uznać jednostkę przestrzeni wyodrębnioną z większego obszaru za pomocą specyficznych kryteriów i jednolitą lub spójną w zakresie tych kryteriów ${ }^{13}$. W art. 16 Konstytucji RP wskazano, że ogół mieszkańców jednostek zasadniczego podziału terytorialnego stanowi z mocy prawa wspólnotę samorządową ${ }^{14}$. W sposób czytelny odwołuje się do tego artykułu Ustawa o samorządzie województwa w art. 1 określa województwo jako regionalną wspólnotę samorządową tworzoną z mocy prawa przez mieszkańców województwa oraz odpowiednie terytorium $^{15}$. Ich właściwością jest terytorium, rozumiane jako oznaczony obszar geograficzny wchodzący w skład Rzeczpospolitej Polskiej, zapewniający decentralizację

11 M. Perkowski, Międzynarodowa współpraca..., op. cit., s. 296.

12 J.Z. Pietraś, Polityka zagraniczna państwa, (w:) Współczesne stosunki międzynarodowe, T. Łoś-Nowak (red.), Wrocław 1995, s. 52.

13 B. Dolnicki, Region samorządowy, (w:) Prawo międzynarodowe europejskie i krajowe - granice i wspólne obszary. Księga jubileuszowa dedykowana Profesor Genowefie Grabowskiej, B. Mikołajczyk, J. Nowakowska-Małusecka (red.), Katowice 2009, s. 168-170. Por.: W. Żelazny, Region w Unii Europejskiej, „Przegląd Zachodni” 1997, nr I, s. 65; T. Parteka, Regiony i system terytorialny, (w:) Regiony, Z. Brodecki (red.), Warszawa 2005, s. 63 i n.; Z. Chojnicki, T. Czyż: Region - regionalizacja - regionalizm, „Ruch Prawniczy, Ekonomiczny i Socjologiczny” 1992, nr 2. 
władzy oraz zdolność do wykonywania ich zadań (art. 15 Konstytucji RP), a także możliwość zachowania więzi historycznych, społecznych i gospodarczych między mieszkańcami oraz świadomości wspólnoty ${ }^{16}$.

Jednostki samorządowe w Polsce, a do nich zalicza się województwa, są samodzielnymi podmiotami administracji, strukturami publicznymi samorządnymi, cechującymi się odrębnością własnych praw i obowiązków oraz określonym zakresem swobody funkcjonowania. Dzięki przyznanej podmiotowości prawnej ${ }^{17}$, jednostki samorządu terytorialnego mają zagwarantowaną samorządność, dzięki której mogą wykonywać zadania publiczne w imieniu własnym i na własną odpowiedzialność ${ }^{18}$, także w relacjach z naczelnymi organami państwowymi oraz organami administracji rządowej ${ }^{19}$. Ze względu na realizowane zadania publiczne można stwierdzić, że województwo samorządowe jest wspólnotą o charakterze regionalnym. Z punktu widzenia efektywności i racjonalności utworzenie regionów i powierzenie im realizacji zadań publicznych (w tym współpracy zagranicznej, w szczególności z innymi jednostkami samorządu terytorialnego odpowiadającymi polskim województwom) było motywowane dbałością o ich wykonywanie na właściwym poziomie. Czy jednak polskie województwa są regionami w europejskim tego słowa znaczeniu?

Choć w praktyce pojawiły się wątpliwości, czy województwa samorządowe powstałe po reformie administracyjnej stanowią regiony, to jednak w doktrynie w sposób na ogół jednoznaczny opowiedziano się za takim stanowiskiem ${ }^{20}$. Województwo samorządowe w sensie ustrojowym i terytorialnym uznawane jest za region. Stanowi ono wyodrębnioną, najwyższą jednostkę podziału terytorialnego państwa, zlokalizowane jest pomiędzy państwem a powiatami i gminami. Jego władze są niezależne od administracji rządowej. Ma osobowość prawną. Organy województwa samorządowego pochodzą z wyborów. Z mocy prawa otrzymało własne zadania i kompetencje oraz budżet z własnymi dochodami. Wątpliwości budzi jedynie warunek posiadania obszaru stosunkowo jednolitego pod względem gospodarczym, społecznym i kulturowym ${ }^{21}$.

16 M. Perkowski, Międzynarodowa współpraca..., op. cit., s. 20.

17 Uzasadnienie do wyroku TK z dnia 29.10.2009 r. (K 32/08, OTK-A 2009, nr 9, poz. 139).

18 Por.: Z. Niewiadomski, Samorząd terytorialny, (w:) System prawa administracyjnego, t. 6, Podmioty administrujące, R. Hauser, Z. Niewiadomski, A. Wróbel (red.), Warszawa 2011, s. 125; A. Doliwa, Konstytucjonalizacja osobowości prawnej jako podstawa współpracy międzynarodowej gmin, „Białostockie Studia Prawnicze” 2012, nr 12, s. 211-212.

19 M. Karpiuk, Samorząd terytorialny a państwo. Prawne instrumenty nadzoru, Lublin 2008, s. 57.

20 Ibidem, s. 33. Por.: A. Gajda, Regiony w prawie wspólnotowym. Prawne problemy udziału regionów polskich w procesach integracyjnych, Warszawa 2005, s. 131-135; J. Lemańska, Koncepcja samorządu województwa na tle porównawczym, Kraków 2006, s. 20; M. Słok, Pojęcie regionu w prawie europejskim i polskim, (w:) Wdrażanie zobowiązań międzynarodowych Polski w związku z członkostwem w Unii Europejskiej, cz. 2, Ogólne zagadnienia wdrażania prawa UE i wybrane zagadnienia branżowe, M. Żylicz (red.), Radom 2005, s. 25-27.

21 Prawo administracyjne. Pojęcia, instytucje, zasady w teorii i orzecznictwie, M. Stahl (red.), Warszawa 2002, s. 222; Z. Leoński, Samorząd terytorialny w RP, Warszawa 1999, s. 130; H. Izdebski, Samorząd terytorialny. Podstawy ustroju i działalności, Warszawa 2001, s. 118; Z. Cieślak, I. Lipowicz, Z. Niewiadomski, Prawo administracyjne - część ogólna, Warszawa 2002, s. 148; K. Jóskowiak, Samorząd terytorialny..., op. cit., s. 11. 
Wydaje się, że można uznać polskie województwa samorządowe za regiony europejskie ${ }^{22}$. Trzeba jednak zdawać sobie sprawę, że na razie modele regionów zaproponowane przez Radę Europy sytuują polskie regiony (samorządy województw) stosunkowo „nisko” w stosunku do innych regionów europejskich pod kątem uprawnień legislacyjnych, jak również ze względu na brak gwarancji konstytucyjnych ${ }^{23}$. Bolesław Woś twierdzi nawet, że polskie regiony wydają się być ułomnymi podmiotami (brak samodzielności, zaplecza; nie jest w pełni realizowana w Polsce Europejska Karta Samorządu Terytorialnego) ${ }^{24}$. Wydaje się, że problemem, ale i szansą dlań jest aktywność międzynarodowa, która stanowi „chleb powszedni” regionów europejskich $^{25}$. Jaki jest status prawny tej aktywności?

\section{Współpraca zagraniczna polskich regionów w świetle}

\section{prawa}

Polskie województwa (podobnie jak inne europejskie regiony) upatrują swej szansy w stosunkach międzynarodowych, niewątpliwie w nich uczestnicząc, na różnych poziomach publicznych i międzysektorowych (różne konfiguracje) ${ }^{26}$. Nawiązują i utrzymują współpracę $\mathrm{z}$ analogicznymi podmiotami zagranicznymi (niekiedy współpracę bliźniaczą - twinning), obejmującą: zawieranie porozumień, uczestnictwo $\mathrm{w}$ pracach organizacji międzynarodowych (lobbing, procesy decyzyjne, konsultacje, zarządzanie funduszami zagranicznymi z budżetów organizacji międzynarodowych), międzynarodowe zrzeszanie się, tworzenie przedstawicielstw, realizacja projektów międzynarodowych. Odbywa się to na warunkach określonych przez prawo wewnętrzne oraz umowy międzynarodowe. Mimo pewnego zakresu kontroli odpowiednich władz państwowych, władze terytorialne dysponują sporym zakresem swobody, co pozwala traktować je jako odrębnych od państw uczestników stosunków międzynarodowych ${ }^{27}$. Wydaje się, że aktualnie nawet bierna ich postawa wystarcza, by wskutek skierowanych doń działań partnerów zza granicy doszło do ich umiędzynarodowienia ${ }^{28}$.

Por.: A. Gajda, Regiony w prawie wspólnotowym..., op. cit., s. 137-143.

J. Olbrycht, Status regionów a programowanie na poziomie regionalnym, ekspertyza wykonana na zlecenie Departamentu Koordynacji Polityki Strukturalnej w MGPiPS, Warszawa 2005, www.funduszestrukturalne.gov.pl/ NR/.../npr0713_status_regionow.doc (data dostępu: 11.01.2016 r.), s. 12. Por.: Idem, Status regionów a programowanie na poziomie regionalnym, (w:) Perspektywy rozwoju lokalnego i regionalnego w warunkach akcesji Polski do Unii Europejskiej. Programowanie - Zarządzanie - Zmiany Społeczno-Ekonomiczne, A. Barcik, R. Barcik (red.), Bielsko-Biała 2004, s. 11-27.

B. Woś, Rozwój regionów i polityka regionalna w Unii Europejskiej oraz w Polsce, Wrocław 2005, s. 19.

M. Perkowski, Międzynarodowa współpraca..., op. cit., s. 35.

Powiązania zewnętrzne. Modernizacja Polski, W. Morawski (red.), Warszawa 2012. Por.: M. Perkowski, Status prawny polskich województw w stosunkach międzynarodowych. Uwagi na tle rozwoju prawa międzynarodowego, (w:) Prawo międzynarodowe - teraźniejszość, perspektywy, dylematy. Księga Jubileuszowa Profesora Zdzisława Galickiego, E. Mikos-Skuz, K. Myszon-Kostrzewa, J. Poczobut (red.), Warszawa 2013.

K. Jóskowiak, Samorząd terytorialny..., op. cit., s. 12.

M. Perkowski, Międzynarodowa współpraca..., op. cit., s. 50. 
Jak wskazano na wstępie - aktywność międzynarodowa regionów europejskich zależy głównie od systemu konstytucyjnego państwa ich przynależności ${ }^{29}$. Konstytucja RP określa, że jednostki samorządu terytorialnego mają prawo zrzeszania się, w tym przystępowania do międzynarodowych zrzeszeń społeczności lokalnych i regionalnych oraz współpracy ze społecznościami lokalnymi i regionalnymi innych państw $^{30}$. Jak każda nieomal współpraca w stosunkach międzynarodowych, także i współpraca zagraniczna regionów obramowana jest prawem międzynarodowym. Dla międzynarodowej współpracy polskich regionów znaczące są głównie wiążące Polskę dokumenty powstałe pod auspicjami Rady Europy. Polski standard zagranicznej współpracy samorządowej w znacznym stopniu powstawał pod wpływem treści merytorycznej Europejskiej Karty Samorządu Terytorialnego ${ }^{31}$. Mimo że Europejska Karta Samorządu Lokalnego jest unormowaniem ogólnym, w którym tylko nieliczne postanowienia wprost odnoszą się do współpracy międzynarodowej samorządu terytorialnego, to jednak przestrzeganie jej postanowień wydatnie sprzyja współpracy międzynarodowej polskich województw, tworząc dlań grunt prawny i przewidywalne, stabilne, a nade wszystko ujednolicone (przynajmniej w Europie) standardy $^{32}$. Z kolei ukierunkowana wprost na współpracę międzynarodową samorządu terytorialnego w Europie jest Europejska Konwencja Ramowa o Współpracy Transgranicznej Między Wspólnotami i Władzami Terytorialnymi ${ }^{33}$, czyli Konwencja Madrycka Rady Europy, przyjęta 21 maja 1980 roku. W preambule państwa członkowskie Rady Europy, które podpisały konwencję wskazują na determinację, by w jak najszerszym stopniu wspierać współpracę transgraniczną i w ten sposób przyczyniać się do postępu gospodarczego i społecznego obszarów przygranicznych oraz do umocnienia poczucia wspólnoty, które jednoczy narody Europy. Konsekwentnie potwierdzają to przyjęte zobowiązania ${ }^{34}$. Cezary Mik słusznie zwraca uwagę, że istnieją również regulacje pozarządowe, jak np. Europejska karta regionów granicznych i transgranicznych uchwalona w 1981 roku przez Stowarzyszenie Europejskich Regionów Przygranicznych, bądź transgraniczne, ale niewiążące Polski, jak np. Europejska Karta Samorządu Regionalnego (EKSR) uchwalona w 1997 roku przez Kongres Władz Regionalnych i Lokalnych Rady Europy (IV sesja 3-5 czerwca 1997 roku w Strasburgu) ${ }^{35}$ w formie rekomendowanego dokumentu

29 Ibidem, s. 39. Por.: T. Parteka, Regiony..., op. cit., 66-67.

30 Art. 172 ust. 1 i 2 Konstytucji RP, op. cit.

31 Europejska Karta Samorządu Terytorialnego, sporządzona w Strasburgu 15 października 1985 roku, Dz.U. z 1994 r., Nr 124, poz. 607.

32 M. Perkowski, Główne podstawy prawnomiędzynarodowe aktywności zagranicznej samorządu terytorialnego w Europie, „Białostockie Studia Prawnicze” 2012, nr 12, s. 15.

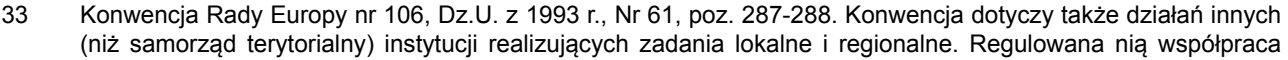
transgraniczna jest pojęciem szerszym niż współpraca zagraniczna województw i innych jednostek samorządu terytorialnego.

34 M. Perkowski, Międzynarodowa współpraca..., op. cit., s. 62.

35 C. Mik, Opinia w sprawie prawnych aspektów aktywności międzynarodowej województw, zawieranych przez nie umów i porozumień oraz kompetencji Ministra Spraw Zagranicznych i Ministra Spraw Wewnętrznych, BAS-WA- 
ramowego. Bardziej szczegółowe ramy formalne współpracy transgranicznej na granicach Polski określają traktaty międzypaństwowe, w których jedną z zasad jest nawiązywanie i rozwój różnych form współpracy transgranicznej. Na ich podstawie zostały zawarte stosowne umowy i porozumienia dające podstawy prawne współpracy polskich władz regionalnych i lokalnych $\mathrm{z}$ ich partnerami w państwach sąsiedzkich $^{36}$. Z perspektywy Polski należy brać pod uwagę prawo Unii Europejskiej, które stanowi odrębny porządek prawny ${ }^{37}$. $\mathrm{Z}$ tego też względu nie można traktować prawa unijnego $\mathrm{w}$ ramach prawa międzynarodowego publicznego, choć z perspektywy praktyki samorządowej może tak wyglądać. W doktrynie panuje pogląd, że prawo Unii Europejskiej upodmiotawia ${ }^{38}$ samorządy regionów w stosunkach europejskich.

Powracając do prawa krajowego - zgodnie z art. 2. ust. 1. Ustawy o zasadach przystępowania jednostek samorządu terytorialnego do międzynarodowych zrzeszeń społeczności lokalnych i regionalnych, jednostki samorządu terytorialnego mogą przystępować do zrzeszeń i uczestniczyć w nich w granicach swoich zadań i kompetencji, działając zgodnie z polskim prawem wewnętrznym, polityką zagraniczną państwa i jego międzynarodowymi zobowiązaniami ${ }^{39}$. Prowadzenie takiej działalności musi być zgodne z prawem krajowym, polityką zagraniczną państwa i jego międzynarodowymi zobowiązaniami, w granicach zadań i kompetencji województwa, dlatego też priorytety współpracy zagranicznej województwa, projekty umów o współpracy zagranicznej oraz umowy o przystąpieniu do międzynarodowych zrzeszeń regionalnych, na podstawie których województwa mogą prowadzić współpracę z zagranicznymi regionami, muszą zostać zaakceptowane przez Ministra Spraw Zagranicznych. Pozwala to na prowadzenie polityki zagranicznej państwa jedynie przez rząd $\mathrm{d}^{40}$. Oprócz wspomnianej wcześniej uchwały zarządu województwa, do aktów kreowanych z poziomu województwa można zaliczyć porozumienia, konwencje itd. Odgrywają ważną rolę, ale w Polsce nie mogą obowiązywać bez potwierdzenia ich przez stronę rządową. Ponadto należy wspomnieć o dokumentach strategicznych - teoretycznie nie wiążą się one ze strategią rozwoju województwa, co stanowi problem - przecież stanowią one punkt wyjścia dla regionalnych programów operacyjnych, kolejnych uchwał, czy wniosków o przystąpienie do zrzeszeń. Pomocniczą rolę pełni orzecznictwo. Dobrym przykładem jest orzecznictwo Trybu-

PEiM-371/13, Warszawa 2013, s. 10. Por.: A. Malinowska, Współpraca zagraniczna samorządu województwa zagadnienia wybrane, „Przegląd Prawa Publicznego” 2012, nr 7-8, s. 138-139.

36 M. Perkowski, Międzynarodowa współpraca..., op. cit., s. 67.

37 Por.: Wyrok Trybunału Sprawiedliwości z 5 lutego 1963 r. w sprawie 26/62 - NV Algemene Transport - en Expeditie Onderneming van Gend \& Loos v. Netherlands Inland Revenue Administration; Wyrok Trybunału Sprawiedliwości z dnia 15 lipca 1964 r. w sprawie 6/64 - Flamino Costa v. E.N.E.L.

38 Por.: C. Mik, Status władz regionalnych i lokalnych państw członkowskich Unii Europejskiej w świetle prawa wspólnotowego, „Ruch Prawniczy, Ekonomiczny i Socjologiczny” 2006, z. 2, s. 239 i n.

39 Ustawa z dnia 15 września 2000 r. o zasadach przystępowania jednostek samorządu terytorialnego do międzynarodowych zrzeszeń społeczności lokalnych i regionalnych, Dz.U. z 2000 r. Nr 91, poz. 1009 ze zm.

40 M. Perkowski, Polskie województwa w stosunkach międzynarodowych, „Białostockie Studia Prawnicze” 2012, nr 12, s. 107. 
nału Konstytucyjnego RP, który uformował uprawnienie do nieskrępowanego tworzenia wspólnoty samorządowej, wskazując, że nie tylko społecznościom lokalnym, jako zbiorowości przepis prawa nadaje podmiotowość w sensie polityczno-socjologicznym (niezależnie od istniejących struktur organizacyjnych), ale daje również mieszkańcom prawo do niezakłóconego pozostawania w istniejących strukturach terytorialno-politycznych, jeśli tylko godzą się na nią, bo respektują wykształcone, zwykle w dłuższym okresie, więzi łączące mieszkańców ${ }^{41}$.

Andrzej Szmyt podkreśla, że jeśli w sprawie współpracy rządu z samorządem terytorialnym w sferze aktywności międzynarodowej tegoż samorządu pojawiłyby się trudności lub niejasności, to najlepszym forum ich rozwiązywania - na etapie wstępnym - mogłaby być Komisja Wspólna Rządu i Samorządu Terytorialnego ${ }^{42}$, przewidziana ustawą z dnia 6 maja 2005 r. o Komisji Wspólnej Rządu i Samorządu Terytorialnego oraz o przedstawicielach Rzeczypospolitej Polskiej w Komitecie Regionów Unii Europejskiej ${ }^{43}$. Ten ostatni organ międzynarodowy od dawna będąc forum dyskusji i pośredniego oddziaływania przedstawicieli samorządu regionalnego (obok samorządowców innych szczebli), zyskawszy zdolność sądową przed unijnymi organami wymiaru sprawiedliwości - stał się potencjalnym ,adwokatem” regionów europejskich w ich dążeniach emancypacyjnych. Wydaje się, że dla relacji polityki zagranicznej państwa i współpracy zagranicznej regionów istotniejsze znaczenie może mieć ustalenie sposobu rozpatrywania sporów, jakie mogą pojawić się między współpracującymi międzynarodowo regionami. Każda współpraca, nawet bardzo udana, determinuje ryzyko konfliktu. Co więcej, im bardziej udana (np. finansowo) jest współpraca, tym większe staje się potencjalne ryzyko. W doktrynie dostrzega się w związku z aktywnością międzynarodową regionów potencjalne pola sporów kompetencyjnych i konfliktów pomiędzy aspiracjami samorządów wojewódzkich, sferą konstytucyjnej i ustawowej samodzielności, sferą autonomii płynącej z osobowości prawnej (swoboda kontraktowa - wolność zawierania porozumień i umów, decydowanie o partnerach, treści i formie porozumień i umów) a dążeniami centrum państwowego zmierzającego do zapewnienia koordynacji działalności samorządów regionalnych w transgranicznej i międzynarodowej współpracy międzyregionalnej ${ }^{44}$.

41 Uzasadnienie wyroku TK z dnia 26.02.2003 r., K 30/02, Legalis.

42 A. Szmyt, Opinia prawna w sprawie współpracy rządu z samorządem terytorialnym w sferze aktywności międzynarodowej samorządu, Biuro Analiz Sejmowych Kancelarii Sejmu z dnia 28 stycznia 2016 r., BAS-WAUiP-53/16, s. 12-13. Autor podkreśla w opinii, że Komisja Wspólna stanowi (art. 2 tejże ustawy) forum wypracowywania wspólnego stanowiska Rządu i samorządu terytorialnego; rozpatruje ona problemy związane z funkcjonowaniem samorządu terytorialnego i z polityką państwa wobec samorządu terytorialnego, a także sprawy dotyczące samorządu terytorialnego znajdujące się w zakresie działania Unii Europejskiej i organizacji międzynarodowych, do których Polska należy.

43 Dz.U. z 2005 r. Nr 90, poz. 759.

44 J. Boć, S. Malarski, Polskie regiony w procesie integracji europejskiej, (w:) Prawne problemy regionalizacji w Europie, K. Nowacki, R. Russano (red.), Wrocław 2008, s. 100. Por.: M. Perkowski, Arbitraż a międzynarodowa współpraca regionów. Uwagi de lege lata i de lege ferenda, (w:) Arbitraż w prawie międzynarodowym, C. Mik (red.), Warszawa 2014, s. 266. 
Ministerstwo Spraw Zagranicznych, w kwestii rozwiązywania ewentualnych sporów, które mogą wynikać ze współpracy międzyregionalnej regionów podkreśla, że co do zasady strony same w dowolnym momencie określają sposób i tryb ich rozwiązywania zgodnie ze swoją wolą, w tym np. poprzez wybór organu rozstrzygającego. Jeśli strony tego nie określą, zastosowanie mają przepisy ustawy z dnia 4 lutego 2011 r. - Prawo prywatne międzynarodowe ${ }^{45}$ oraz rozporządzenia Parlamentu Europejskiego i Rady (WE) nr 593/2008 z dnia 17 czerwca 2008 r. w sprawie prawa właściwego dla zobowiązań umownych (Rzym I) ${ }^{46}$, które określają sposób ustalania prawa właściwego dla zobowiązań umownych ${ }^{47}$. Tym samym państwo zdaje się postrzegać międzynarodową współpracę regionów, jako obszar właściwości prawa prywatnego. Tymczasem - poza tym, że prowadzą ją podmioty prawa publicznego, to $\mathrm{w}$ dodatku skupiają się $\mathrm{w}$ jej ramach na zagadnieniach publicznych. Zawierane porozumienia na ogół kształtowane są na wzór umów międzypaństwowych i w zbliżonym duchu, tworząc ramy przyszłej współpracy, czasem wyznaczając jej obszary i niemal każdorazowo - przewidując wzajemne negocjacje, jako mechanizm rozwiązywania ewentualnych sporów. Co ciekawe, Załącznik 1 do Konwencji madryckiej - Wzory i zarysy porozumień, statutów oraz umów w dziedzinie współpracy transgranicznej między wspólnotami i władzami terytorialnymi sugeruje prawne możliwości zastosowania arbitrażu do rozwiązywania sporów wynikłych na skutek międzynarodowej współpracy regionów ${ }^{48}$. Po pierwsze - Wzór porozumienia międzypaństwowego o wspieraniu współpracy transgranicznej w art. 6 wskazuje, że strony dołożą starań na rzecz doprowadzenia, w ramach postępowania rozjemczego bądź też w inny sposób, do rozwiązania kwestii spornych o znaczeniu lokalnym, gdy rozwiązanie tych spraw stanowi przesłankę dla pomyślnej realizacji współpracy transgranicznej. Ponadto - Wzór porozumienia międzypaństwowego o umownej współpracy transgranicznej między władzami lokalnymi w art. 5 wskazuje, że w przypadku sporu właściwy sąd jest określony przez prawo, które ma być zastosowane. Umowy o współpracy transgranicznej mogą jednak zawierać klauzule arbitrażowe. Użytkownik i strona trzecia zachowują istniejące środki prawne wobec

Dz.U. z 2011 r. Nr 80, poz. 432, ze zm. Por.: K. Kentnowska, Rozwój form współpracy samorządów na poziomie międzynarodowym, (w:) Formy współdziałania jednostek samorządu terytorialnego, B. Dolnicki (red.), Warszawa 2012, s. 169.

46

47

48

Urz. UE L 177 z 04.07.2008 r., s. 6

Odpowiedź MSZ na interpelację Posła na Sejm RP Damiana Raczkowskiego z dnia 22 lutego 2013 roku w sprawie aktywności międzynarodowej województw i zawieranych przez nie umów oraz porozumień, sygn. SPS-02314604/13, udostępniona autorowi i w jego zasobach.

Europejska konwencja ramowa o współpracy transgranicznej między wspólnotami i władzami terytorialnymi, sporządzona w Madrycie w dniu 21 maja 1980 r., Dz.U. z 1993 r. Nr 61, poz. 287. W Załącznikach przewidziano (do wyboru) modelowy asortyment założeń konstrukcyjnych porozumień, umów i statutów odpowiadających różnym stopniom rozwoju i formom współpracy transgranicznej. W zależności od celu oraz stanu wewnętrznych przepisów prawnych owe wzory i zarysy mogą być zastosowane bezpośrednio bądź też będą wymagały zawarcia porozumień międzypaństwowych o ich zastosowaniu. Należy wyraźnie zaznaczyć, iż wzory te mają charakter schematyczny, ponieważ nie sposób uwzględnić wszystkich problemów, które mogą wystąpić w poszczególnych przypadkach. Por.: A. Mikołajczyk, Prawne formy współpracy transgranicznej, (w:) Regiony, Z. Brodecki (red.), Warszawa 2005, s. 296-297 oraz 306. 
władz lokalnych państwa, do którego przynależą, przy czym władze te mają obowiązek podjęcia działań wobec partnera nie wywiązującego się z umowy. Władze nadrzędne podejmują wszelkie leżące $\mathrm{w}$ ich mocy działania w celu zapewnienia natychmiastowego wykonania postanowień sądowych, bez względu na to, w którym z państw znajduje się siedziba sądu, który przyjął dane postanowienie. Z kolei Wzór porozumienia międzypaństwowego o organach współpracy transgranicznej między władzami lokalnymi w art. 9 wskazuje, że jeśli dojdzie do ugody, to spory między stowarzyszeniem lub związkiem i członkami oraz spory między dwoma lub większą liczbą członków, dotyczące sposobu działania stowarzyszenia lub związku, rozpatrywane są przez władze administracyjne i sądy państwa, na którego terytorium znajduje się siedziba stowarzyszenia lub związku. Natomiast wszelkie inne spory rozpatrywane są przez władze administracyjne i sądy stosownie do zwykłych przepisów obowiązujących na terytorium państw-sygnatariuszy, jeśli uczestnicy nie uzgodnią przekazania rozstrzygania sporów jednej z wyznaczonych przez nie instytucji arbitrażowych. Oczywiście państwa-sygnatariusze poczynią stosowne kroki w celu zapewnienia wykonywania na ich terytorium decyzji i wyroków wynikających z powyższych postanowień ${ }^{49}$.

Ponadto odniesienie do arbitrażu zawiera Zarys umowy (prawa prywatnego) o zagwarantowaniu dostaw i świadczeń między władzami lokalnymi na obszarach przygranicznych, którym mogłyby się posługiwać władze lokalne przy sprzedaży, najmie, na rynku pracy, przy dostawach towarów i świadczeń, przy odstąpieniu praw użytkownika itd. Stosowanie przez władze lokalne umów prawa prywatnego jest dopuszczane w mniejszym lub większym zakresie przez wewnątrzpaństwowe przepisy prawne i praktykę, a granica między umowami prawa prywatnego i umowami prawa publicznego jest trudna do przeprowadzenia. Pomimo tego dopuszcza się możliwość stosowania tego typu umów, gdy dotyczą one zgodnie z wiodącą w każdym z państw wykładnią spraw o charakterze komercyjnym lub gospodarczym, które mogłyby być również przedmiotem umów zawartych przez osoby fizyczne lub prawne prawa prywatnego. W przypadku każdego przedsięwzięcia, w którym uczestniczyłyby władze lokalne wykonujące uprawnienia pozostające w wyłącznej kompetencji państw, powinny zostać uwzględnione, oprócz niżej przedstawionych postanowień, także przepisy dodatkowe, zawarte w umowie wzorcowej prawa publicznego. Artykuł 7 przewiduje w razie konieczności postępowanie koncyliacyjne oraz określa tryb postępowania arbitrażowego. W razie potrzeby zastosowania postępowania arbitrażowego, komisja arbitrażowa posiadać będzie następujący skład:

- każda ze stron reprezentująca przeciwne interesy mianuje (alternatywa: prezesi właściwych dla każdej ze stron sądów administracyjnych mianują) jednego członka komisji arbitrażowej, a Strony mianują wspólnie jednego lub 
dwóch członków niezależnych, tak aby osiągnąć nieparzystą liczbę członków komisji;

- w przypadku, gdy komisja arbitrażowa składa się z parzystej liczby członków i przy równowadze głosów, decyduje głos niezależnego członka komisji.

Analogiczne rozwiązanie odnieść można do Zarysu umowy (prawa publicznego) o zagwarantowaniu dostaw i świadczeń między władzami lokalnymi na obszarach przygranicznych, który wskazuje, że poza wymienionymi w nim szczególnymi uwarunkowaniami obowiązują postanowienia przewidziane w przedstawionym wyżej zarysie umowy prawa prywatnego. Adam Mikołajczyk podkreśla, że opinie będące rezultatem postępowania arbitrażowego mają charakter niewiążący (a przede wszystkim - nieegzekwowalny za pomocą sankcji prawnych) i pozostają bez mocy prawnej dla stron ${ }^{50}$.

Trzeba dodać, że w przypadku konfliktów występujących pomiędzy współpracującymi regionami różnych państw, głównie w sprawach zawartych porozumień o współpracy regionalnej, zastosowanie mają także regulacje prawne Konwencji o koncyliacji i arbitrażu w ramach KBWE z 1992 roku $^{51}$. Konwencja wskazuje sieć instytucji wspomagających rozwiązywanie sporów, tj. Trybunał Arbitrażowy, Sąd Koncyliacyjny i Arbitrażowy oraz przede wszystkim komisje pojednawcze powoływane w przypadku każdego konfliktu ${ }^{52}$.

Analizując praktykę ustalono, że Komisja Europejska ${ }^{53}$, Ministerstwo Spraw Zagranicznych ani urzędy marszałkowskie oficjalnie nie dysponują informacjami o zaistniałych sporach, w związku z prowadzoną przez regiony współpracą międzyregionalną, ani nie uczestniczy w procesie ich rozwiązywania ${ }^{54}$. Wskazują też, że na obecnym etapie nie widzą potrzeby tworzenia dodatkowych rozwiązań

50 A. Mikołajczyk, Prawne formy współpracy transgranicznej..., op. cit., s. 294-296. Por.: E. Kowalczyk, Mediacja i arbitraż jako przykład interwencji strony trzeciej w negocjacjach gospodarczych, „Ruch Prawniczy, Ekonomiczny i Socjologiczny” 1999, nr 2, s. 186 i 188. Por. M. Perkowski, Arbitraż a międzynarodowa współpraca regionów..., op. cit., s. 268.

51 Konwencja o koncyliacji i arbitrażu w ramach KBWE, sporządzona w Sztokholmie dnia 15 grudnia 1992 r., Dz.U. z 1999 r. Nr 98, poz. 1138.

52 Por. M. Perkowski, Arbitraż a międzynarodowa współpraca regionów..., op. cit., s. 269.

53 Odpowiedź udzielona przez komisarza Johannesa Hahna w imieniu Komisji na zapytanie posła do Parlamentu Europejskiego Krzysztofa Liska, Bruksela 11.10.2013, E-009568/2013, udostępniona autorowi i w jego zasobach. Uczestnicy badania ankietowego zostali poproszeni o potwierdzenie bądź zaprzeczenie formalnej możliwości stawania, jako strona przed sądami międzynarodowymi, lub trybu uzyskiwania w ramach procesu odpowiedzi na pytania prawne. Wyniki wskazują, iż prawie połowa (aż 6 ankietowanych województw) nie była w stanie odpowiedzieć na pytanie. Pozostała liczba respondentów potwierdziła zdolność sądową województw (3 pozytywne wskazania), w tym zdolność szczególną - różniącą się od zdolności państwowej, jednak charakterystyczną dla krajowych osób prawnych (2 wskazania). Kategorię „inne” wybrało 3 uczestników badania zwracając uwagę na kompetencje określone ustawą o samorządzie województw. Paradoksalnie - zapytani o obszary sporne we współpracy międzynarodowej - respondenci wskazali, że zasadniczo nie są stroną sporów międzynarodowych, jednakże wskazali na określne potencjały. Największą liczbę konfliktów ankietowani wskazali w obszarze ochrony zdrowia. Wskazania środka tabeli należą do obszaru rozwoju regionalnego. Za najmniej konfliktogenne respondenci uznali przedsięwzięcia z zakresu sportu, turystyki i ochrony środowiska (to ostatnie zastanawia). Ankietowani wskazali, że np. planów zagospodarowania przestrzennego (regiony przygraniczne). Badania własne z I. 2012-2013, opisane wraz z wnioskami w: M. Perkowski, Międzynarodowa współpraca województw..., op. cit., s. 181-255. 
prawnych w tym zakresie. To ciekawy pogląd, zwłaszcza w obliczu nieustannych zmian, z których część jest widoczna. Przykładowo, w związku z pojawianiem się europejskiego ugrupowania współpracy terytorialnej, w przypadkach sporów, których stroną jest EUWT, aktualnie zastosowanie znajdują regulacje prawa unijnego w zakresie jurysdykcji, a w sytuacjach nieprzewidzianych takim prawodawstwem unijnym - sądami właściwymi do rozwiązywania sporów są sądy państwa członkowskiego, w którym znajduje się siedziba statutowa EUWT. Tu warto przypomnieć zasadę traktowania krajowego, zgodnie z którą władze państwa traktować powinny związki i stowarzyszenia transgraniczne w sposób analogiczny (z uwzględnieniem jedynie niezbędnych modyfikacji) jak własne - jednolicie krajowe formy i struktury współpracy ponadgminnej (związki komunalne czy międzygminne, stowarzyszenia gmin). Adam Mikołajczyk zwraca uwagę, że stowarzyszenie lub związek - z tytułu zadań publicznych, których wykonywanie przejął od swoich członków - odpowiada także wobec użytkowników i osób trzecich. Podobnie jak ma to miejsce w przypadku innych form współpracy, procedury rozstrzygania sporów powstałych na tle regionalnego porozumienia o utworzeniu wspólnych organów transgranicznych przewidywać mogą różne rodzaje postępowań polubownych, łącznie z wyznaczeniem właściwych instytucji arbitrażowych ${ }^{55}$. To zależy jednak od państwa... Tak oto - jakbyśmy nie rozważali współpracy międzynarodowej regionów - zależy ona od polityki zagranicznej państwa, której treść wypełnia z kolei (m.in.) ta pierwsza.

\section{Wnioski końcowe}

Wydaje się, że tytułowa zależność (polska polityka zagraniczna a współpraca międzynarodowa regionów) nie wpisuje się wprost ani w poglądy monistyczne (gr. monos - jeden) przyjmujące lub głoszące jednorodność rozpatrywanej dziedziny, ani też w poglądy dualistyczne (łac. dualis - podwójny) dopatrujące się jej dwoistości. Przyczyny doktrynalnego rozróżnienia między monistami i dualistami tkwią w odmiennych zapatrywaniach na naturę regionów i pozycję prawną państw ${ }^{56}$. Aktualnie można mówić o sytuacji hybrydalnej, bliższej dualizmowi, choć monizm byłby tu za wszech miar pożądany. W polityce zagranicznej państwa zbyt mało miejsca poświęca się współpracy międzynarodowej regionów, a szkoda. Trudno oczekiwać, że regiony bez polityki w zakresie współpracy międzynarodowej będą ją realizowały systematycznie, perspektywicznie i podmiotowo. Niezrozumiałe jest, dlaczego państwo - zawłaszczając całość polityki zagranicznej, wskazując województwom zasadność współpracy międzynarodowej - samo w swej polityce zagranicznej nie

\footnotetext{
55 A. Mikołajczyk, Prawne formy współpracy transgranicznej..., op. cit., s. 308. Por. M. Perkowski, Arbitraż a międzynarodowa współpraca regionów..., op. cit., s. 269-270. 
kładzie dostatecznego nacisku na aktywność regionów na forum międzynarodowym oraz nie uszczegóławia i nie konkretyzuje swej praktyki pod kątem regionów ${ }^{57}$.

Według Michała Kuleszy mimo upływu kilkunastu już lat współpracy międzynarodowej województw, wciąż mają one kłopoty w relacjach z MSZ. Nie ma żadnych stałych mechanizmów współpracy MSZ z samorządami regionalnymi, nie ma stałego sekretariatu dla tych spraw, a polskie ambasady nie mają poczucia, że współpraca zagraniczna samorządów wymaga wsparcia z ich strony. Praktyczny zakres współpracy zagranicznej polskich samorządów jest bardzo rozległy i bardzo istotny, nie tylko dla każdego z polskich regionów, lecz także dla skuteczności polskiej polityki zagranicznej w ogólności - twierdzi Michał Kulesza, dodając, że szkoda to marnować i konieczna jest większa aktywność i koncentracja MSZ na omawianym problemie $^{58}$.

Aktualne priorytety polskiej polityki zagranicznej uwzględniają umiędzynarodowienie regionów, wskazując, że dla ułatwienia ich działań w zakresie współpracy międzynarodowej należy pogłębić i rozszerzyć zakres dokumentów centralnych, w których tematyka może dotyczyć współpracy międzyregionalnej, a także opracować dokumenty zajmujące się analizą działań polskich regionów w dziedzinie współpracy międzyregionalnej (międzynarodowej i krajowej) oraz transgranicznej. Dostrzegalne też jest niezbyt efektywne wykorzystywanie procedury konsultowania dokumentów tworzonych przez regiony $\mathrm{w}$ dziedzinie współpracy międzynarodowej z resortami centralnymi ${ }^{59}$. W praktyce nie funkcjonuje należyty mechanizm zarządzania danymi o współpracy zagranicznej regionów. Zasadna jest także bieżąca aktualizacja poszczególnych priorytetów współpracy zagranicznej województwa, które tworzono ponad 10 lat temu, niezbyt dużą wagę przykładając do ich jakości (przy równoczesnym braku określonego wzorca) ${ }^{60}$. Wydaje się, że optymalny byłby model, gdzie przygotowania polityki zagranicznej państwa byłyby poprzedzone przygotowaniem polityki zagranicznej regionów (oddolnie, ale w określonych normach i praktykach), które następnie byłyby wspólnie (w układzie rząd - regiony) dyskutowane, weryfikowane i przełożyłyby się na fragment polityki zagranicznej państwa w odniesieniu do regionu. Wówczas dylematy jak np. w sytuacji, gdy województwo podlaskie chciałoby „ocieplenia relacji” z Białorusią, a MSZ priorytetowo

Relacje państwa i regionu wobec terytorium można przyrównać do relacji właściciela i użytkownika nieruchomości, na której ten ostatni (odpłatnie) prowadzi działalność zarobkową, podnosząc tym samym jej wartość. Jeśli owa działalność funkcjonuje dobrze - właściciel nieruchomości na tym korzysta, w dodatku progresywnie. Jeśli zaś funkcjonuje źle - właściciel traci (nawet jeśli nie od razu, to ostatecznie, ale traci). Zdrowy rozsadek podpowiada tu, co najmniej, koegzystencję, a optymalnie - kooperację, w kierunku jednoczesnej optymalizacji korzyści obu stron.

M. Kulesza, Opinia, (w:) M. Bonikowska, G. Lipski, K. Żurek, Polska polityka zagraniczna. Perspektywa samorządów i obywateli. Władze samorządowe, uczelnie, organizacje pozarządowe i think tanki o swojej roli w polityce zagranicznej państwa oraz o potrzebie współpracy z instytucjami centralnymi. Decentralizacja debaty oraz zadań w polskiej polityce zagranicznej. Kwestie do debaty, Warszawa 2012.

59 Por.: Priorytety polskiej polityki zagranicznej 2012-2016, Warszawa 2012.

60 Por.: M. Kołodziejski, K. Szmigiel, Międzynarodowa współpraca transgraniczna i międzyregionalna w kontekście polityki regionalnej państwa na lata 2007-2013 (ekspertyza wykonana na zlecenie Departamentu Polityki Regionalnej w MGiP), Warszawa 2004. 
traktuje batalię polityczną o demokrację i prawa człowieka, byłyby przekształcane w racjonalny kompromis pozwalający utrzymać priorytety polityki zagranicznej państwa przy uwzględnieniu społeczno-gospodarczych potrzeb regionu. „Ambiwalencję” warto zastąpić tu „empatycznym zdecydowaniem”...

\section{BIBLIOGRAFIA}

Boć Jan, Stanisław Malarski. 2008. Polskie regiony w procesie integracji europejskiej. W: Prawne problemy regionalizacji w Europie. Konrad Nowacki, Robert Russano (red.), 79-114. Wrocław: Kolonia Limited.

Chojnicki Zbyszko, Teresa. Czyż. 1992. „Region - regionalizacja - regionalizm”. Ruch Prawniczy, Ekonomiczny i Socjologiczny 2 (54): 1-18.

Cieślak Zbigniew, Irena Lipowicz, Zygmunt Niewiadomski. 2002. Prawo administracyjne - część ogólna, Warszawa: LexisNexis.

Doliwa Adam. 2012. „Konstytucjonalizacja osobowości prawnej jako podstawa współpracy międzynarodowej gmin”. Białostockie Studia Prawnicze (12): 209-218.

Dolnicki Bogdan. Region samorządowy. 2009. W: Prawo międzynarodowe europejskie i krajowe - granice i wspólne obszary. Księga jubileuszowa dedykowana Profesor Genowefie Grabowskiej, 166-189. Barbara Mikołajczyk, Joanna Nowakowska-Małusecka (red.). Katowice: Wydawnictwo Uniwersytetu Śląskiego.

Gajda Anastazja. 2005. Regiony w prawie wspólnotowym. Prawne problemy udziału regionów polskich w procesach integracyjnych. Warszawa: Wydawnictwo Prawo i Praktyka Gospodarcza.

Gryz Jarosław. 2004. Proces instytucjonalizacji stosunków transatlantyckich. Warszawa: Wydawnictwo Naukowe Scholar.

Izdebski Hubert. 2001. Samorząd terytorialny. Podstawy ustroju i działalności. Warszawa: LexisNexis.

Jóskowiak Kazimierz. 2008. Samorząd terytorialny w procesie integracji europejskiej Polskie doświadczenia i wnioski na przyszłość. Katowice: Wydawnictwo Uniwersytetu Śląskiego.

Karolina Kentnowska. 2012. Rozwój form współpracy samorządów na poziomie międzynarodowym. W: Formy współdziałania jednostek samorządu terytorialnego, 234-251. Dolnicki Bogdan (red.). Warszawa: Wolters Kluwer business, 2012.

Karpiuk Mirosław. 2008. Samorząd terytorialny a państwo. Prawne instrumenty nadzoru Lublin: Wydawnictwo Katolickiego Uniwersytetu Lubelskiego.

Kołodziejski Marek, Katarzyna Szmigiel. 2004. Międzynarodowa współpraca transgraniczna i międzyregionalna w kontekście polityki regionalnej państwa na lata 2007-2013 (ekspertyza wykonana na zlecenie Departamentu Polityki Regionalnej w MGiP). Warszawa: Centrum Rozwoju Lokalnego.

Kościk Bogdan, Sławińska Magdalena (red.). 2010. Zrównoważony rozwój terenów przygranicznych. Lublin: Wydawnictwo Katolickiego Uniwersytetu Lubelskiego.

Kowalczyk Elżbieta. 1999. „Mediacja i arbitraż jako przykład interwencji strony trzeciej w negocjacjach gospodarczych”. Ruch Prawniczy, Ekonomiczny i Socjologiczny (2): 185-198. 
Kukułka Józef. 2000 Teoria stosunków międzynarodowych. Warszawa: Wydawnictwo Naukowe Scholar.

Kulesza Michał. 2012. Opinia. W: Małgorzata Bonikowska, Grzegorz Lipski, Kazimierz Żurek. Polska polityka zagraniczna. Perspektywa samorządów i obywateli. Władze samorządowe, uczelnie, organizacje pozarządowe i think tanki o swojej roli w polityce zagranicznej państwa oraz o potrzebie współpracy z instytucjami centralnymi. Decentralizacja debaty oraz zadań w polskiej polityce zagranicznej. Kwestie do debaty, 13. Warszawa: Ośrodek Analityczny THINTANK.

Lemańska Joanna. 2006. Koncepcja samorządu województwa na tle porównawczym. Kraków: Uniwersytet Jagielloński.

Leoński Zbigniew. 1999. Samorząd terytorialny w RP, Warszawa: C.H. Beck.

Malinowska Agnieszka. 2012. „Współpraca zagraniczna samorządu województwa - zagadnienia wybrane". Przegląd Prawa Publicznego (7-8): 134-149.

Mik Cezary. 2006. „Status władz regionalnych i lokalnych państw członkowskich Unii Europejskiej w świetle prawa wspólnotowego". Ruch Prawniczy, Ekonomiczny i Socjologiczny (2): 221-252.

Mik Cezary. 2013. Opinia w sprawie prawnych aspektów aktywności międzynarodowej województw, zawieranych przez nie umów i porozumień oraz kompetencji Ministra Spraw Zagranicznych i Ministra Spraw Wewnętrznych. BAS-WAPEiM-371/13. Warszawa: Biuro Analiz Sejmowych Kancelarii Sejmu.

Mikołajczyk Adam. 2005. Prawne formy współpracy transgranicznej. W: Regiony. Zdzisław Brodecki (red.), 291-317. Warszawa: Wydawnictwo Naukowe PWN.

Morawski Witold (red.). 2012. Powiązania zewnętrzne. Modernizacja Polski. Warszawa: Wydawnictwo Wolters Kluwer SA.

Niewiadomski Zygmunt. 2011. Samorząd terytorialny. W: System prawa administracyjnego, t. 6, Podmioty administrujące. R. Hauser, Z. Niewiadomski, A. Wróbel (red.), 97-226. Warszawa: C.H. Beck.

Olbrycht Jan. 2004. Status regionów a programowanie na poziomie regionalnym. W: Perspektywy rozwoju lokalnego i regionalnego w warunkach akcesji Polski do Unii Europejskiej. Programowanie - Zarządzanie - Zmiany Społeczno-Ekonomiczne. Anna Barcik, Ryszard Barcik (red.), 11-27. Bielsko-Biała: Wydawnictwo Akademii Techniczno-Humanistycznej.

Olbrycht Jan. 2005. Status regionów a programowanie na poziomie regionalnym (ekspertyza wykonana na zlecenie Departamentu Koordynacji Polityki Strukturalnej w MGPiPS). Warszawa: www.funduszestrukturalne.gov.p1/NR/.../npr0713_status_regionow.doc .

Parteka Tomasz. 2005. Regiony i system terytorialny. W: Regiony. Zdzisław Brodecki (red.), 63-65. Warszawa: Wydawnictwo Prawnicze LexisNexis.

Perkowski Maciej. 2012. „Główne podstawy prawnomiędzynarodowe aktywności zagranicznej samorządu terytorialnego w Europie”. Białostockie Studia Prawnicze (12): 13-22.

Perkowski Maciej. 2012. „Polskie województwa w stosunkach międzynarodowych”. Białostockie Studia Prawnicze (12): 105-112.

Perkowski Maciej. 2013. Międzynarodowa współpraca województw w prawie i praktyce. Białystok: Wydawnictwo Temida2. 
Perkowski Maciej. 2013. Status prawny polskich województw w stosunkach międzynarodowych. Uwagi na tle rozwoju prawa międzynarodowego. W: Prawo międzynarodowe - teraźniejszość, perspektywy, dylematy. Księga Jubileuszowa Profesora Zdzisława Galickiego. Elżbieta Mikos -Skuza, Katarzyna Myszona-Kostrzewa, Jerzy Poczobut (red.), 83-94. Warszawa: Wydawnictwo Wolters Kluwer.

Perkowski Maciej. 2014. Arbitraż a międzynarodowa współpraca regionów. Uwagi de lege lata i de lege ferenda. W: Arbitraż w prawie międzynarodowym, Cezary Mik (red.), 257-270. Warszawa: C. H. Beck.

Pietraś Jacek Z. 1986. Podstawy teorii stosunków międzynarodowych. Lublin: Wydawnictwo UMCS.

Pietraś Jacek Z. 1995. Polityka zagraniczna państwa. W: Współczesne stosunki międzynarodowe. Teresa Łoś-Nowak (red.), 11-38. Wrocław: Wydawnictwo Uniwersytetu Wrocławskiego.

Popiuk-Rysińska Irena. 1994. Uczestnicy stosunków międzynarodowych, ich interesy i oddziaływania. W: Stosunki międzynarodowe. Geneza, struktura, funkcjonowanie. Edward Haliżak, Irena Popiuk-Rysińska (red.), 88-118. Warszawa: Wydawnictwo Uniwersytetu Warszawskiego.

Skorowski Henryk. 16 czerwca 2011. Regionalizm czynnikiem dynamizmu współczesnego państwa. Warszawa: tekst wygłoszony podczas Mazowieckiego Sejmiku Kultury (maszynopis).

Słok Magdalena. 2005. Pojęcie regionu w prawie europejskim i polskim, [w:] Wdrażanie zobowiązań międzynarodowych Polski w związku z członkostwem w Unii Europejskiej, cz. 2, Ogólne zagadnienia wdrażania prawa UE i wybrane zagadnienia branżowe. Marek Żylicz (red.). Radom: Wyższa Szkoła Handlowa.

Stahl Małgorzata (red.). 2002. Prawo administracyjne. Pojęcia, instytucje, zasady w teorii i orzecznictwie. Warszawa: Wydawnictwo Wolters Kluwer business.

Szmyt Andrzej. 28 stycznia 2016 r. Opinia prawna w sprawie współpracy rządu z samorządem terytorialnym w sferze aktywności międzynarodowej samorządu. BAS-WAUiP-53/16. Warszawa: Biuro Analiz Sejmowych Kancelarii Sejmu.

Szymański Janusz. 2002. Podstawy prawne współpracy transgranicznej i regionalnej Polski ze wschodnimi sąsiadami. Suwałki: maszynopis udostępniony przez autora, w związku z brakiem egzemplarzy drukowanych.

Tomaszewski Krzysztof. 2007. Regiony w procesie integracji europejskiej, Warszawa: Wilga.

Warleigh-Lack Alex., Malin Stegmann Stegmann. 2012. “'Usages of Europe' and Europeanisation: Evidence from the Regionalisation of Sweden”. European Integration 34 (4): 379-396.

Wierzbicki Bogdan (red.). 2008. Prawo międzynarodowe publiczne. Materiały do studiów. Białystok: Wydawnictwo Temida2.

Wlaźlak Katarzyna. 2010. Rozwój regionalny jako zadanie administracji publicznej. Warszawa: Wydawnictwo Wolters Kluwer SA.

Woś Bolesław. 2005. Rozwój regionów i polityka regionalna w Unii Europejskiej oraz w Polsce. Wrocław: Oficyna Wydawnicza Politechniki Wrocławskiej.

Żelazny Walter. 1997. „Region w Unii Europejskiej”. Przegląd Zachodni (1): 61-78. 


\section{THE DEPARTING AMBIVALENCE OF THE EXECUTIVE POWER, OR FOREIGN COOPERATION OF POLISH REGIONS VS THE STATE'S FOREIGN POLICY}

Foreign activity of European regions depends on their national (constitutional) status. In unitary states, the status is relatively the weakest, rarely explicitly recognized in Constitutions (e.g. in the Netherlands and Portugal), and legal sovereignty belongs exclusively to central authorities. Whereas in federal states, under federal Constitutions it is divided between the federation and its members, which significantly increases independence of the latter, also in the international sphere. Not so broad but still significant activity is demonstrated by regions in regionalised countries, which represent an intermediate form between a federal state and a unitary state with a decentralized structure, where regions are delineated by the Constitution (being a legal guarantee of their existence) and, in addition, have a specific competence in the field of executive power, but without legislative and judicial powers. Such intrastate units benefit from constitutionally guaranteed autonomy, as a territorial division is based mostly on recognition of regions due to their historical traditions or and indwelling ethnic or language group. Given that regionalised countries, such as Spain and Italy, were previously managed as completely unitary ones, the idea that states which are today unitary may become a subject to regionalization in future appears. Certainly, it is not a desired state from the point of view of unitary executive authorities. Therefore, it most probably provokes ambivalence in the approach of regions to foreign activity, in the sense that "it is not proper to prohibit it, encouraging it causes little fear, so it has to be tolerated". Is it relevant for the relation between foreign cooperation of Polish regions and the state's foreign policy? In a nutshell: "for now, it is". However, "constant rubbing wears away the stone" and external conditions (examples and financial incentives), as well as regional initiatives, transfer foreign cooperation from the realm of "event" into the realm of "professional activity".

Keywords: regions, voivodships, regions and international cooperation, state foreign policy, internationalization of regions, international law of local self-government

Słowa kluczowe: regiony, województwa, regiony i współpraca międzynarodowa, polityka zagraniczna kraju, umiędzynarodowienie regionów, międzynarodowe prawo samorządu terytorialnego 